\title{
Learning by doing. \\ Case study: education for sustainable development at the University of Latvia
}

\author{
Dina Bērziņa \\ University of Latvia
}

\section{Article Info}

Received Dec 31 $1^{\text {st }}, 2018$

\section{Keyword:}

Education for sustainable development

European research programmes

ICT tools for learning Integrative approaches Knowledge management

\begin{abstract}
Junction of possibilities offered by European research programmes in the tertiary education and technology enhanced learning open up new borders for students and young researchers; especially for the ones from institutions with less strong collaboration links to Western-Europe and overseas.

University of Latvia has undertaken the challenge of designing master's programme on education for sustainable development called 'Natural Sciences, Global Change and Technologies for Sustainable Development' combined with application of digital learning tools. Teaching staff was formed form several faculties of the University of Latvia, other universities, respective companies as well as foreign partner institutions to ensure transdisciplinarity and broad application of different learning tools. Along with the tuition, also international conferences and summer schools were organised. Open discussions among foreign professors and youngsters facilitate more rapid promotion of the latter. Now our students demonstrate recognised success, e.g., have joined research community in Max Planck Society, and have won the Energy Globe Award in the field of education for sustainable development.

The paper describes a case study of transforming the master's programme curriculum by employing various methods and tools.
\end{abstract}

\section{Corresponding Author:}

\section{Dina Bērziņa}

Institute of Atomic Physics and Spectroscopy,

University of Latvia,

Raina Blvd.19, Riga, LV 1586, Latvia.

Email: Dina.Berzina@lu.lv

\section{Introduction}

The traditional picture of a student sitting in a large auditorium has been alternated - students can complete their education at any time, place and age in a variety of educational formats. Nowadays the information and communication technology (ICT) is a basic component in the educational system and has an important role in development of the knowledge society. Learning has become more student centered seeking to identify tools that would match students' interests and goals.

The use of ICTs in learning process has been recognised as a tool to increase access and quality of education at all levels starting with the framework ones, e.g., United Nations Sustainable Development Goal No 4 for education, SDG4 [1] to national strategies and local implementation plans. One of the innovation leaders in Europe, Finland (Innovation index 0.65 [2]) in 2010 has adopted the National Plan for Educational Use of Information and Communications Technology highlighting sustainable and systemic change including school infrastructure and support services, learner's future skills, as well as teacher's identity, training and 
pedagogical expertise. The technical solutions selected must be cost-efficient, of high quality and chosen with due consideration for the perspective of sustainability [3].

The evolution of education for sustainable development at the University of Latvia has followed the same trends as discussed by Walter Leal Filho regarding sustainable development in higher education institutions [4].

In Latvia first sprouts, at that time called 'environmental education', broke out during 1989-1990 when environmental science and environmental management elements were included in a number of university curricula. Worth mentioning are educators who have developed this activity most widely, namely at the University of Latvia: Faculty of Chemistry, Faculty of Geography and Geology (currently Geography and Earth Sciences), Faculty of Economics and Management (currently Business, Management and Economics), Faculty of History and Philosophy and the Riga Technical University: Faculty of Chemistry (currently Materials Science and Applied Chemistry), Faculty of Energetics (currently Power and Electrical Engineering). Simultaneously, the Ecological Centre of University of Latvia and the Children Environmental School initiated informal environmental education in schools and among the society as a whole.

Dedicated environmental science programmes on tertiary level at the University of Latvia could be found since 1990; in 1990 - Faculty of Chemistry started the programme on Environmental Science; 1992 - Centre for Environmental Science and Management Studies (CESAMS) launched the first interdisciplinary master's degree programme on environmental management at the same time offering separate courses for bachelor students [5]. When Latvia became a part of the Baltic University Programme network focusing on issues of education for sustainable development and sustainability in the Baltic Sea region, Latvian students obtained possibility of taking part in international interdisciplinary programmes on sustainable development. Available tertiary education programmes in early $21^{\text {st }}$ century in Central-Eastern Europe focusing on sustainability issues were collected by author of this publication and reported at the $4{ }^{\text {th }}$ COPERNICUS Conference 'Higher Education for Sustainability' [6]; and for Latvia (mainly in natural sciences) - at the $4^{\text {th }}$ Symposium 'Environment and Universities in Europe' [7].

Education for sustainable development (ESD) defined as 'education that promotes each individual's ability to acquire the knowledge, values and skills needed to participate in decision-making on individual or collective activities at the local and global level in order to improve the quality of life at present without endangering the needs of future generations' in Latvia officially was recognised in 2014 by adopting Guidelines for Education development prescribing that all educational system curricula should include elements and principles of education for sustainable development [8].

Information and communication technologies have been utilised by education sector since their inception, but vastly presented - only since the early 1990s. One of the first applications of ICT for ESD in Latvia were digital games which were popular among all ages and presented themselves as an ideal platform to deliver outcomes of learning by doing. The pioneer in teaching sustainability through simulation and gaming in Latvia was the Ecological Centre of University of Latvia [9].

\section{Initial efforts}

Encouraged by the success and attractiveness of CESAMS educational programmes, the elaboration of interdisciplinary master's programme in sciences based on principles of sustainable development was initiated at the Faculty of Physics and Mathematics, Institute of Atomic Physics and Spectroscopy. The first trial was pilot project in 1995 'Physics and environmentally safe future technologies in BSc and MSc programmes' anticipating inclusion of separate courses in undergraduate and graduate studies.

Accurately designed 3-year project 'Physics and Technologies for Sustainable Development' funded by the Latvian Environmental Protection Fund was launched in 1997. Its goals were:

- to create the necessary base for education and research in the field of sustainable technologies;

- to develop the Faculty of Physics and Mathematics along with its research institutes into a centre for science and education in the field of sustainable development;

- to frame a one-stop info-point with an extensive library involving also potential students' employers.

The activities covered:

- inclusion of separate courses on sustainable technologies for undergraduates and graduates;

- operating the centre for consultancy on education and technologies for sustainable development;

- elaboration of a new graduate (master's) sub-programme 'Physics and Technologies for Sustainable development'. 
Unfortunately, the project was closed down after the first year as unconformable with the Environmental Protection Fund's objectives. The team continued to work voluntarily offering students a possibility for elaborating their MSc and BSc thesis on sustainability issues. The results were reported at several international conferences: $2^{\text {nd }}$ Pan-European Conference 'EURO ENVIRONMENT', Denmark [10]; $6^{\text {th }}$ auDes Conference 'Bridging Minds and Markets', Italy [11]; $4^{\text {th }}$ World Environmental Education Congress, South Africa [12].

\section{Transformation of the Traditional Curriculum}

Linking of smart technologies research to industry is an important issue in modern manufacturing; and the supply of human capital understanding sustainable development issues is crucial. Considering the experience gained during the pilot courses, a scrupulously designed MSc programme 'Innovations in Physics master's programme "Physics for Global change and Sustainable development"' was elaborated in 2006 as a response to fast-growing corporate demand for professionals who can integrate production in energy-saving, waste-free and zero-emission packages. The project was supported by the European Social Fund [13] and aimed at:

- increasing the number of students at tertiary studies in physics;

- diversifying study opportunities by extending the training scope of specialists;

- starting to meet the market needs for specialists having good knowledge of physics, and at the same time understanding the link between global change and technological development.

Participants of the earlier pilot courses were especially encouraged for the full-time master's studies involving research training and elaboration of thesis across different university faculties or other institutions in Latvia. In the course of implementation this MSc programme, study council realised the necessity to extend the program, thus covering all natural and part of social sciences regarding issues of sustainable development. The pilot programme was updated to transdisciplinary graduate studies' programme 'Natural sciences, Global change and Technologies for Sustainable development' at that time being the only one at the University of Latvia engaging professors, researchers and experts from various organisations and countries to insure full transdisciplinarity in science education for sustainable development, Table 1 [14]. Our empirical revelations correspond to Paula Lindroos findings within the Baltic University Programme network - internationalisation and networking improve the opportunities for common workshops, courses and competence development. By introducing sustainability in education, research and management, the involved researchers, teachers and students cooperate at a macro-regional level [15].

The new MSc programme was compiled of four thematic modules:

- module of science comprising geophysics, environmental physics, biophysics, green chemistry, and the science of the atmosphere;

- module of technologies offering courses on renewable energy technologies, closed production cycles (now called 'circular economy'), nanotechnologies and space technologies including monitoring issues;

- module of corporate responsibility dealing with business and ethics, marketing of new technologies, basis of EU and Latvian environmental law, environmental management including ISO 14000 series standardisation;

- module of research methods providing basic and ad-hoc training in labs and fundamentals of modelling methods.

Along with the theoretical studies, interactive workshops and field trials, students had an opportunity of participating at international events for advanced training and presenting their research findings on sustainability issues. Professors also were engaged in in-service training on sustainable development issues mutually enriching themselves by following specific lectures delivered by Latvian colleagues, active participation in guest readings organised during the pilot course, visiting partner institutions and sharing their experience at international conferences, Table 2. Our findings on influence of the formation of educators on tutoring for sustainable development are similar to the ones presented in collection of the case studies summarised by Walter Leal Filho and Paul Pace [16]. 
Table 1: Contributors to implementation of the MSc programme 'Natural sciences, Global change and Technologies for Sustainable development'

\begin{tabular}{ll}
\hline \multicolumn{1}{c}{ Organisation type / Country } & \multicolumn{1}{c}{ Entity } \\
\hline Education - University of Latvia, faculty & Faculty of Business, Management and Economics \\
Education - University of Latvia, faculty & Faculty of Chemistry \\
Education - University of Latvia, faculty & Faculty of Geography and Earth Sciences \\
Education - University of Latvia, faculty & Faculty of Physics, Mathematics and Optometry \\
Education - university & Latvia University of Agriculture \\
Education - university & Riga Technical University \\
Education - university & Turiba University \\
Research - University of Latvia, institute & Institute of Atomic Physics and Spectroscopy \\
Research - University of Latvia, institute & Institute of Chemical Physics \\
Research - University of Latvia, institute & Institute of Solid State Physics \\
Research - institute & Latvian Institute of Aquatic Ecology \\
Research - institute & Latvian State Institute of Wood Chemistry \\
Research - institute & Ventspils International Radio Astronomy Centre \\
Governmental agency & North Vidzeme Biosphere Reserve \\
Governmental agency & Latvian Geospatial Information Agency \\
Governmental agency & Patent office of the Republic of Latvia \\
Entrepreneur & Grindeks, JSC \\
Finland - education & University of Turku, Archipelago Research Institute \\
Germany - education & Institute of Environmental Physics, University of \\
Germany - research & Bremen \\
Italy - education & German Research Centre for Geosciences, Potsdam \\
Sweden - education & University of Naples \\
Switzerland - education & Baltic University Programme \\
United Kingdom - education & University of Bern \\
\hline
\end{tabular}

ICT is a critical mechanism that can improve access to education and addresses issues relating to inclusion, equity and quality - i.e., sustainable development goal for education, SDG4; further, it plays also a transformative role in raising public awareness and reducing the cost of extending services to wider audience. Therefore, the programme possessed not only new thematic structure, but incorporated also new tools. Course outlines and presentations were available in Moodle learning system open to all pilot programme students and lecturers thus providing an opportunity of following the lectures in e-environment as all the students of the pilot course were permanently employed adults and experienced skipping of lectures due to business trips, family affairs, etc. The offer was highly appreciated also by our teaching staff. Further, open educational resources provide a solution that reduces the cost of specialised materials for students and increases reliance on digital resources. Among new tools employed, the study course on Research methods - Computer modelling for Environmental management needs should be specially noted. It was designed to provide an overview of modern computer modelling, possibilities and methods (i.e., software) and practical aspects for employing them. Last but not least to be mentioned is interactive teaching of Environmental management systems. Along with 'traditional lectures', also multimedia CD Reality Interactive ${ }^{\mathrm{TM}}$ were utilised for practical training. After the computer supplied lectures, success stories and practical exercises students were asked to test their knowledge by short quizzes designed to ensure understanding of the material. At the end of the course there was an overall test - on successful passing the test students received their certificate on accomplishing the study course [17]. 
Table 2: Students' practice \& Teachers' mobility and experience sharing

\begin{tabular}{|c|c|c|c|c|}
\hline Country & Event type & Event, year & No of students & No of teachers \\
\hline Austria & summer school & $\begin{array}{l}6^{\text {th }} \text { Workshop on Advances in Energy } \\
\text { Studies 'Towards a holistic approach } \\
\text { based on science and humanity', } 2008\end{array}$ & 1 & \\
\hline Austria & conference & $\begin{array}{l}\text { Engineering Education in Sustainable } \\
\text { Development, EESD-2008 }\end{array}$ & & 1 \\
\hline Belgium & workshop & $\begin{array}{l}\text { EU Parliament workshop } \\
\text { 'Nanotechnologies - Risks or } \\
\text { Opportunities?', } 2007\end{array}$ & & 1 \\
\hline Belgium & conference & $\begin{array}{l}4^{\text {th }} \text { Annual Brussels Climate Change } \\
\text { Conference, } 2008\end{array}$ & & 1 \\
\hline Finland & in-service training & $\begin{array}{l}\text { University of Turku, Archipelago } \\
\text { Research Institute; Turku Science } \\
\text { Park; Turku - Åbo municipality, } 2008\end{array}$ & 6 & 1 \\
\hline Germany & in-service training & $\begin{array}{l}\text { Institute of Environmental Physics, } \\
\text { University of Bremen, } 2007\end{array}$ & & 1 \\
\hline Greece & in-service training & $\begin{array}{l}\text { National Technical University of } \\
\text { Athens, } 2007\end{array}$ & & 1 \\
\hline Italy & summer school & $\begin{array}{l}3^{\text {rd }} \text { European Advanced Course on } \\
\text { Emergy and Complex Systems, } 2008\end{array}$ & 3 & 2 \\
\hline Latvia & 'night' & EU Researchers' night, 2006-2008 & & $\sim 20$ \\
\hline Latvia & conference & $\begin{array}{l}\text { Conference on valorisation of the } \\
\text { results of European educational } \\
\text { programmes, } 2007\end{array}$ & & 1 \\
\hline Latvia & conference & $\begin{array}{l}\text { Support of the European Structural } \\
\text { Funds to the development of tertiary } \\
\text { education in Latvia, } 2007\end{array}$ & & 1 \\
\hline Latvia & site visit & $\begin{array}{l}\text { Ventspils International Radio } \\
\text { Astronomy Centre, 2007-2008 }\end{array}$ & 13 & 5 \\
\hline Latvia & summer school & $\begin{array}{l}\text { North Vidzeme Biosphere Reserve, } \\
2008\end{array}$ & 9 & 3 \\
\hline Latvia & conference & $\begin{array}{l}\text { International conference Eco-Balt } \\
2008\end{array}$ & & 2 \\
\hline Netherlands & summer school & $\begin{array}{l}\text { University of Utrecht Summer school } \\
\text { 'Physics of the Climate System', } 2008\end{array}$ & 1 & \\
\hline South Africa & conference & $\begin{array}{l}4^{\text {th }} \text { World Environmental Education } \\
\text { Congress, } 2007\end{array}$ & & 1 \\
\hline United Kingdom & in-service training & University of East Anglia, 2007 & & 1 \\
\hline
\end{tabular}

\section{Further developments}

Currently there is no completely integrated MSc or BSc course on Education for sustainable development at the University of Latvia. There is an inter-faculty professional BSc programme for Teachers in Natural sciences and Information technologies involving teaching staff from different faculties: Chemistry; Biology; Computing; Physics, Mathematics and Optometry; Geography and Earth Sciences. There are BSc and MSc programmes in Environmental Science at the Faculty of Geography and Earth Sciences. There is a professional MSc programme for Teachers in Natural sciences at the Faculty of Education, Psychology and Art dealing with education for personal and sustainable well-being and sustainable development.

Although beloved by students, appraised by European Researchers' night visitors and highly appreciated by foreign partners, the pilot programme 'Natural sciences, Global change and Technologies for Sustainable 
development' never habituated permanently within the University of Latvia curricula due to decreasing number of students and the global economic situation. As before, the team of enthusiasts continued voluntarily on training of highly skilled labour force in science and technology intensive sectors to overcome the gap created by the frame and isolated structure of study programmes. The main activities were extracurricular consultations and possibilities of elaborating MSc and BSc thesis in the field of technologies for sustainable development. Since the Baltic See region countries are leaders on global scale in meeting the environmental, social, and economic challenges of the sustainable development, student in-house training activities were supplemented by organising international conferences with accompanying discussion sessions or summer schools (one-week training) aiming at:

- promoting integration of researchers from traditional sciences into the European and global networks contributing to education for sustainable development;

- promoting the transfer of knowledge and experience from established researchers and recognised scholars to young scientists thus contributing in advanced transdisciplinary training of young researchers;

- discussing corporate responsibility and sustainability in the decision-making process.

After the project, series of conferences and workshops were organised on separate issues of sustainable development research and technologies starting with the general one: $3^{\text {rd }}$ International Conference on Integrative approaches towards sustainability 'Sustainable development, Knowledge society and Smart manufacturing technologies - KNOWLEDGE' in 2012, (https://www.lu.lv/knowledge) followed by more specific ones on:

- biophotonics including environmental sensors:

$\checkmark 1^{\text {st }}$ International Conference 'Biophotonics - Riga 2013';

$\checkmark 2^{\text {nd }}$ International Conference 'Biophotonics - Riga 2017',

- space technologies:

$\checkmark 1^{\text {st }}$ International Conference on Nocturnal Atmosphere, Remote Sensing and Laser Ranging: 'NOCTURNAL - Riga 2014';

$\checkmark$ ILRS Technical Workshop 'Improving ILRS Performance to meet future GGOS Requirements', 2017 ,

- photonics technologies:

$\checkmark 1^{\text {st }}$ International Conference on Photonics technologies: Photonics Technologies - Riga 2012;

$\checkmark$ FOTONIKA-LV $5^{\text {th }}$ anniversary conference 'Achievements and Future prospects', 2015;

$\checkmark$ International Day of Photonics, 2015;

$\checkmark$ International Day of Photonics, 2016;

$\checkmark 2^{\text {nd }}$ FOTONIKA-LV conference 'Achievements and Future prospects', 2017.

Apart from representatives of Baltic Sea Region countries, also participants from other European countries, USA, Australia, New Zealand and Turkey having the will, knowledge and skills to identify options for change towards sustainable development and interested in designing and promotion of alternative integrative solutions were engaged. Although different by theme, content and participation, all organised conferences and training sessions:

- encouraged young scientists to take advantage of opportunities offered by the European Research Area and by the challenge of an integrated approach to the complexity of sustainable development issues;

- motivated the participating researchers, politicians, and economists on targeting the strategy and actions towards sustainable development by discussing corporate responsibility and sustainability on various levels;

- promoted networks of excellence in the respective fields by contributing to development of the mission approach: research and education for sustainable development in knowledge society.

Digital technologies are an incorporated part of today's learning process and education system leading towards better adaptation for life and work. Worth saying, in previous chapters described efforts and success was possible only by the help of new generation tools today broadly available in our every-day life. Since the ICT is developing very rapidly; accordingly, the whole educational system should be reformed by integrating ICT into educational activities. Nowadays the ICT, especially internet plays an important role in the education process of empowering the technology into the learning activities at school, home or lifelong-learning. Internet is not only the most effective way to increase the students' knowledge, but also provides opportunities for Skype discussions, presentations at conferences and broadcasting them. This tool was widely employed in organisation and holding of our workshops, conferences and communication with international educators. 


\section{Source projects and Recognition}

The described activities towards developing education for sustainable development for this team of enthusiasts were possible thanks to several Latvian and EU financed projects. In particular:

- Environmental Education College (1995-1998) - project No JEP09364-95 funded by EU PHARE/TEMPUS programme;

- Physics and Environmentally safe future technologies in BSc and MSc programmes (1995) - funded by Ministry of Education and Science, Republic of Latvia;

- Physics and Technologies for Sustainable Development (1997-2000, planned/ 1997-1998, realised) project No 119 funded by the Latvian Environmental Protection Fund;

- Criteria for the greening of programmes in higher education in Europe (2001-2003) - funded by the European Sustainable Solutions for Existing and New City Environments - ESSENCE network;

- International Conference on 'Integrative Approaches towards Sustainability - TOWARDS', Baltic Sea Region taking the lead (2002-2004) - project No HPCF-CT-2002-00102 funded by EC FP5;

- Atmospheric composition change: A European network - ACCENT (2004-2009) - project No 505337 funded by EC FP6;

- International Conference on 'Integrative Approaches towards Sustainability - SHARING', Baltic Sea Region sharing knowledge internally, across Europe, and world-wide (2004-2006) - project No 9244 funded by EC FP6;

- Natural sciences, Global change and Technologies for Sustainable development (2006-2008) - project No 2006/0253/VPD1/ESF/PIAA/06/APK/3.2.3.2./0089/0063 funded by the European Social Fund;

- Spectrometric techniques for detection of Heavy metal contaminants (2009-2012) - project No 2009/0210/1DP/1.1.1.2.0/09/APIA/VIAA/100 funded by the European Social Fund;

- Unlocking and Boosting Research Potential for Photonics in Latvia - Towards Effective Integration in the European Research Area (2012-2015) - project No 285912 funded by EC FP7;

- EU policies impact to the transformations of the higher education and research system in Norway and Latvia (2016-2017) - Norway Grant No NFI/R/2014/006.

Institute of Atomic Physics and Spectroscopy, University of Latvia, the leading institution for development of innovations in the MSc programme 'Natural sciences, Global change and Technologies for Sustainable development' has received Energy Globe Award - at the world's most prestigious competition on success stories dealing with environmental challenges across about 180 countries. The award for training of youth on sustainability was handed off on an official ceremony at the European Parliament on May 26, 2008. In 2013 University of Latvia received another Energy Globe Award for Series of Conferences on Integrative Approaches towards Sustainability and was entitled as Energy Globe Ambassador, Picture 1 [18].
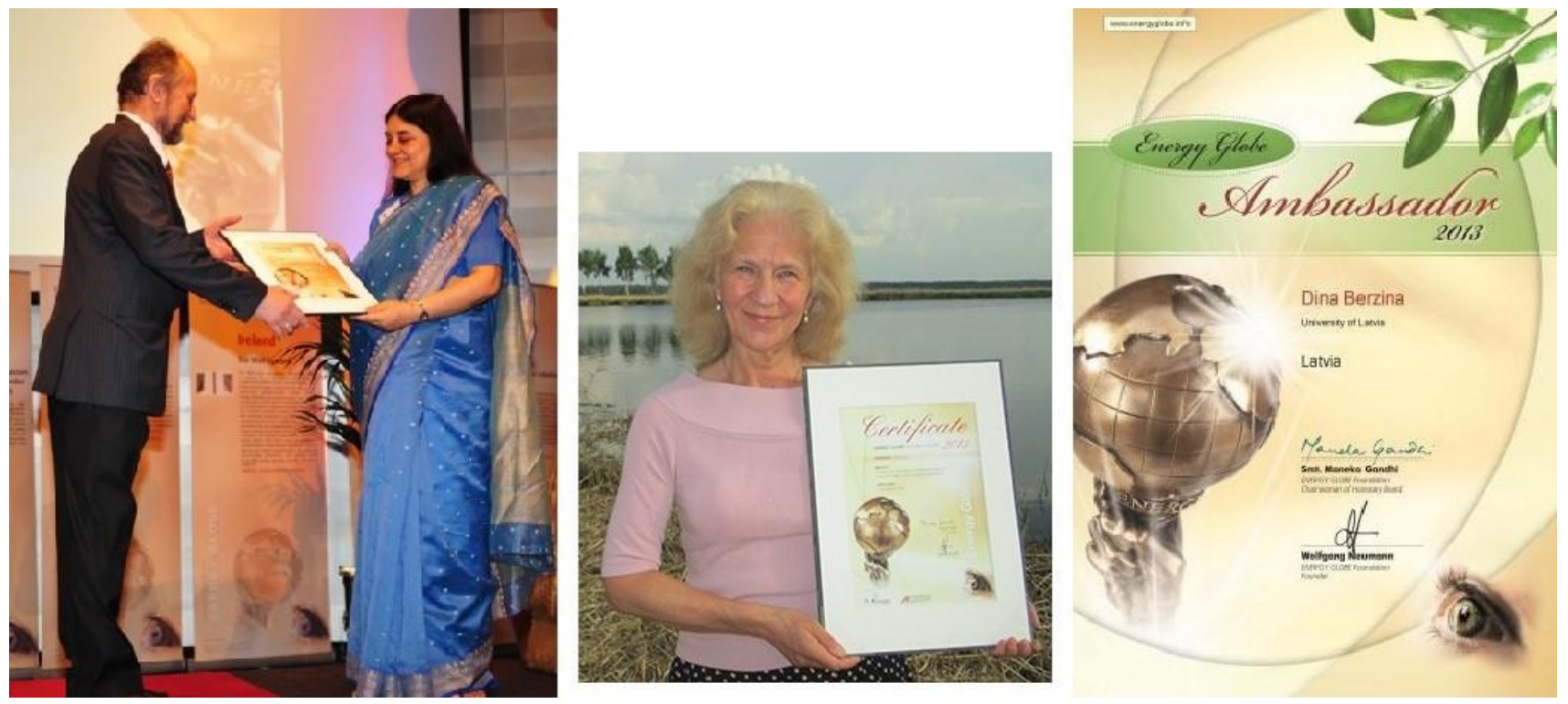

Figure 1. Energy Globe Awards 2008 and 2013 [18]. 


\section{Conclusion}

The 'Sustainable Development Strategy of Latvia until 2030' adopted in 2010 [19] directs towards meeting challenges and opportunities of education, among which is also SDG4 - sustainable development goal for education. However, the lack of an innovative approach and flexible point of view for decision makers in higher education system were at the heart of many country's problems for years. Therefore, strengthening of the human potential is crucial for future contribution to implementation of the sustainable development strategies in EU, particularly for Latvia. Knowledge is at the basis of competitiveness driven by researchers, engineers and technicians; therefore, special attention must be paid to training and recruiting of young graduates, PhDs and fellows for research careers. This is in line with the said of the preceding Prime Minister of the Republic of Latvia at the Davos Forum 2018 indicating that the prerequisite for our future development and competitiveness more and more is depending on labour force - highly intelligent and educated. So, personalities are at the centre. Quality of the education, lifelong learning, research and innovation are the components, whose role will be decisive in a competitive economy [20].

The activities described have committed in reaching the overall objective of the pilot projects: to ensure that employers in Latvia have highly qualified specialists in the field of innovative technologies for sustainable development. During the pilot MSc programme, a group of 25 students were trained. The main outcome is mobilisation of human resources in Latvia for advancement of sustainability and promotion of education for sustainable development. As examples of particularly successful career development and further involvement in the implementation of sustainability issues could be mentioned:

- our student is the head of department in Latvenergo - the largest power supply company in Latvia;

- our student is senior research fellow at Max Planck Institute for Chemistry (Germany);

- our students have established a company and have received the prestigious 'Seal of Excellence' under the Horizon 2020 competition for SME Instrument proposals;

- our student has received the Energy Globe - the world award for sustainability for training the youth in Latvian Museum of Natural History 'Environmental Education and Green Knowledge Transfer';

- the case study elaborated by a group of secondary school students on urban planning in the city of Liepāja and presented at our sustainability conference was recognised by the City Council specialists concluding their elaborated alternatives are as professional as the ones prepared by consulting agencies.

\section{Acknowledgements}

Special acknowledgements to the enthusiastic team leader Arnolds Übelis - the initiator, creator and driving force of innovations in master's study programme and experienced lecturer Jānis Āboliņ̧̌s - the designer of the academic study frame and main curriculum modules.

The publication is supported by ERDF project 1.1.1.5./18//I/016.

\section{References}

[1] United Nations. Transforming our world: the 2030 Agenda for Sustainable Development; 2015. [cited 2019 April 10]. Available from: https://sustainabledevelopment.un.org/post2015/transformingourworld

[2] European Commission. European Innovation Scoreboard 2018. [cited 2018 December 10]. Available from: https://interactivetool.eu/f/extensions/DGGROW4/DGGROW4.html

[3] Finnish National Agency for Education. Finnish National Plan for Educational Use of Information and Communications Technology; 2010. [cited 2018 December 28]. Available from: www.edu.fi/download/135308_TVT_opetuskayton_suunnitelma_Eng.pdf

[4] Leal Filho W. Applied Sustainable Development: A Way Forward in Promoting Sustainable Development in Higher Education Institutions. In: Leal Filho W, editor. World Trends in Education for Sustainable Development. Peter Lang D; 2014, pp. 11-30.

[5] Ministry of Environmental Protection and Regional Development. Environmental education review; 2000 (in Latvian). [cited 2018 December 28]. Available from: www.varam.gov.lv/files/text/Vides_izglitibas_parskats.doc

[6] Bērziña D. Sustainability in higher education - Case study: CEE countries. Presented at $4^{\text {th }}$ International COPERNICUS Conference Higher Education for Sustainability - Towards the World Summit on Sustainable Development 2002, Lüneburg, Germany, October 8-10, 2001. 
[7] Bērziņa D. Natural Science programmes at Universities in Latvia. In: Umwelt und Universitäten in Europa. Konstanz: Umwelt und Wohnen; 2003, p. 119-128.

[8] Guidelines for Education development in Latvia. Latvijas Vēstnesis. 103 (5163), OP 2014/103.1, 2014 (in Latvian).

[9] Bisters V. Teaching Sustainability through Simulation and Gaming. In Proc. 27 $7^{\text {th }}$ Annual International Conference of International Simulation and Gaming Association; 1997. Riga: Vide, pp. 17-24.

[10] Bērziņa D, Āboliņš J, Ūbelis A. The Project of 'Physics and Sustainable Technologies'. In Proc. $2^{\text {nd }}$ PanEuropean Conference 'EURO ENVIRONMENT'. Aalborg, Denmark; 2000. CD: ISBN 87-988254-0-2.

[11] Bērziņa D, Āboliņ̌s J, Ūbelis A. Science for Sustainable Technologies at the University of Latvia. In Proc. $6^{\text {th }}$ International auDES Conference - Bridging Minds and Markets: Emerging Issues in Environmental Education and Employment in Europe. Venice, Italy; 2001, pp. 256-260.

[12] Ūbelis A, Ābolinšs J, Bērziņa D. Teaching Physics and Sustainability. Presented at $4^{\text {th }}$ World Environmental Education Congress (WEEC). Durban, South Africa; July 2-6, 2007.

[13] University of Latvia, Institute of Atomic Physics and Spectroscopy. Public Survey; 2008 (in Latvian). [cited 2018 April 10]. Available from: www.asi.lv/New/2008 parskats[2] IZM.htm

[14] Ubelis A, Abolins J, Berzina D, Blahins J, Bajars G. Graduate Studies of Global Change at the University of Latvia. In: Leal Filho W, editor. Universities and Climate Change - Introducing Climate Change to University Programmes. Climate Change Management Serries. Springer, Berlin, Heidelberg; 2010. pp. 259-269.

[15] Lindroos P. Introducing Education for Sustainable Development - Challenges for Students and Teachers. In: Leal Filho W, Ūbelis A, Bērziña D, editors. Sustainable Development, Knowledge Society and Smart Future Manufacturing Technologies. World Sustainability Series. Springer, Cham; 2015. pp. 33-39.

[16] Leal Filho W, Pace P, editors. Teaching Education for Sustainable Development at University Level. World Sustainability Series. Springer, Cham; 2016.

[17] Bērziņa D. Sustainable Technologies and ISO 14000 Standards at the University of Latvia. In Proc. EcoManagement and Auditing Conference; 1999. pp. 52-61.

[18] Energy Globe - The world award for sustainability. [cited 2018 December 28]. Available from: https://www.energyglobe.info; www.energyglobe.com/download/index/mediafile/2919/Latvia_Arnolds_Ubelis.jpg;

www.energyglobe.info/storage/gallery/78624.JPG; www.energyglobe.info/awards/ambassador/country/76

[19] Saeima of the Republic of Latvia. Sustainable Development Strategy of Latvia until 2030'; June 2010. [cited 2018 April 10]. Available from: https://www.pkc.gov.lv/sites/default/files/inlinefiles/LIAS_2030_en_1.pdf

[20] Cabinet of Ministers of the Republic of Latvia. The Prime Minister takes part in a high-level debate in Davos on the future of Europe; 2018 (in Latvian). [cited 2018 December 27]. Available from: https://mk.gov.lv/lv/aktualitates/ministru-prezidents-davosa-piedalas-augsta-limena-diskusijas-pareiropas-nakotni

\section{BIBLIOGRAPHY OF AUTHOR}

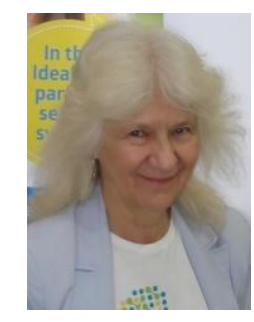

Dina Bērziṇa

is researcher and educator at the University of Latvia, Institute of Atomic Physics and Spectroscopy. Currently dealing with Global Change, Smart Cities and Education for Sustainable Development. Extensive experience in European Union Framework programmes for Research and Development - has been acting as National contact point (including National NCP coordinator) 1999-2017 and performed inservice training on research management across more than 10 Research promotion institutions in Europe. Experience in managing more than 20 European projects 